\title{
NO MAIS ENTRANHADO DA CIDADE: \\ IMAGENS E ESPACIALIDADES DOS BECOS NO CENTRO HISTÓRICO DO RECIFE
}

\author{
- PRISCILA BATISTA VASCONCELOS* \\ - CAIO AUGUSTO AMORIM MACIEL *
}

Resuma: Us becas da Centra Histórica da Recife sãa uma herança sócio-espacial da urbanismo lusa-brasileira, caracterizanda-se como estreitas vias transversais de ligação entre ruas principais. Historicamente relacionados à saciabilidade das mais pobres, safreram, por conseguinte, um processa de ocultaçãa na iconagrafia representativa da cidade, muito embora sejam espaças de intenso fluxo comercial e de serviças. Como lugares entranhadas no tecido urbano, parecem pouco atrativos ac olhar contemplativo ou indignos de registro em gravuras e fotografias. A pesquisa considera a constataçãa empírica da invisibilizaçãa dessas vielas no conjunta do perímetro patrimanializado dos bairros de São Jasé e Santo Antônio para realizar uma reflexão sobre sua espacialidade. Parte-se da chave conceitual da paisagem não panarâmica, num percurso investigativa alicerçada pela produção de fotografias autorais, consideradas enquanto um dispositivo concreto que conduz a descobertas sobre a relação entre perceber e produzir imagens do munda.

Palavras-chave: Becos, Fotografia, Paisagem não panorâmica, Centro Histórica, Recife.

Introdução

A aproximação do tema deste artigo se deu a partir de pesquisa sobre a dinâmica do mercado imobiliário em centros históricos brasileiros, especialmente o Centro Histórico do Recife $^{1}$. A relevância social do estudo está calcada no fato de, recentemente, ocorrer um aceleramento na dinâmica de 
revalorização dos antigos bairros das grandes cidades brasileiras, com resultados ainda imprevisíveis sobre a conservação de determinadas formas no interior dos perímetros tombados. Ressalta-se que entre meados dos anos 1970 e os anos 1990, aconteceu um forte processo de degradação infraestrutural nesses centros, com o deslocamento de população e atividades para as novas centralidades urbanas que foram impulsionadas pelas políticas nacionais de habitação e, simultaneamente, pelas políticas de conservação patrimonial, densamente concentradas nos reconhecidos centros de origem dessas cidades (BERNARDINO; LACERDA, 2015).

Ao adentrarmos na realidade do Recife, evidencia-se o traçado marcante de parte dessa urbe histórica que remonta a um acúmulo de tempos desde a Cidade Maurícia2 do século XVII, através das ruas, becos e pátios dos bairros de São José e Santo Antônio. Supomos que esse traçado espacial imprima uma lógica de "situação" que se reverte atualmente em renda de monopólio para os sujeitos envolvidos no mercado imobiliário, o que gera um mapa de preços pouco encontrado em outras áreas consideradas históricas da cidade do Recife. Essa lógica de situação, para além das questões do mercado imobiliário, confere uma base para diversas espacialidades construídas na história, com diferenças sociais, materiais e imagéticas.

A partir da diversidade morfológica da urbe histórica - numa classificação geral: ruas, pontes, pátios e becos - optamos por entender os becos em sua espacialidade e imagem. Tal escolha sustenta-se, primeiro, pela hipótese de que no espaço dos becos o metro quadrado tenha um preço mais elevado no mercado imobiliário de aluguel de comércio e serviços proporcionalmente comparado ao valor de áreas e prédios localizados nas ruas. Consideramos que isto se deve ao intenso fluxo de pessoas que ali circulam, condição primordial em termos do giro do capital comercial e que interfere no aumento da concorrência por espaço entre os comerciantes (formal e informal). A possibilidade dos becos se apresentarem como um dos espaços mais valorizados na dinâmica do mercado imobiliário desse centro urbano-histórico nos causou inquietação por constatarmos um processo paradoxal de invisibilização desse tipo de lugar no cenário do perímetro patrimonializado pelo Estado.

Além dessa aparente contradição valorização/invisibilização que aguça o ímpeto de pesquisa, também nos interessa compreender o caráter de intenso 
movimento desse interstício espacial. Espaço dos fluxos, uma paisagem do movimento com temporalidade definida: enquanto há luz solar, diurna, é o horário comercial que dita o movimento - estamos de partida com interesse de pesquisa nesse intervalo do chronos, quando os bairros históricos são densamente vivenciados pela população.

Ao abrirmos a escala de análise, percebemos que os becos em estudo estão inseridos num espaço que se conforma hoje como uma "ilha" formada a partir de intervenções urbanísticas ao longo do século XX. Esse bloco, que guarda uma centralidade comercial e histórica e uma paisagem cultural da cidade, pode ser afetado no sentido de mudanças em suas funcionalidades e morfologia, principalmente nas áreas fora do perímetro de preservação rigorosa3, por grandes projetos urbanos privados os quais consideramos fronteiras emergentes de valorização do capital imobiliário. Assim sendo, reside aí uma urgente necessidade de pesquisa, e de pesquisa visual dos becos, para impulsionar a reflexão sobre a importância da conservação desses espaços quaseinvisíveis no contexto de áreas onde incidem políticas de conservação e preservação histórica.
Partindo do discurso contextual, o artigo apresenta o primeiro resultado da pesquisa através de um percurso que se esboçou, primeiramente, no entendimento dos becos como uma herança espacial colonial. Para realizar tal percurso nos concentramos numa geografia histórica imagética do espaço em questão. Após esse apanhado inicial, nos deparamos com o fato da ocultação histórica dos becos tanto no sentido social como no sentido de uma cena urbana que, ao nosso ver, é digna de nota. A partir daí, seguimos com o objetivo de compreender as espacialidades e imagens com a entrada conceitual de paisagem num sentido que foge ao debate consolidado de panorama, propondo a ideia de paisagem entranhada.

Com base na mobilização dessas reflexões, além da pesquisa documental textual e fotográfica, realizamos análise a partir de produção fotográfica autoral. Acionamos e propomos um jogo de olhares que faça aflorar novas cenas investigativas para a compreensão do objeto paisagístico "beco", considerando com Besse (2014) que a fotografia é um dispositivo e suporte concreto que provoca questionamentos sobre a relação entre perceber e produzir imagens do mundo.

A perspectiva, ainda, é pensar com as imagens, segundo a presunção de 
Gomes e Ribeiro (2013, p.28), tratando-as como elementos primários da pesquisa, uma vez que "participam diretamente na construção do pensamento geográfico”. Para esses autores, as imagens incorporam sempre uma expressão física ou suporte pelo qual tomam forma, jamais sendo puramente abstratas, adquirindo, portanto, um potencial de descoberta do mundo muito útil para a démarche geográfica, inclusive no campo da percepção e descrição.

Gomes e Ribeiro propõem ao mesmo tempo o conceito de "reflexividade" (idem, p.31) para definir a especificidade da construção das imagens em espaços públicos, denominando-a como a propriedade desses lugares de gerarem uma ilimitada e recíproca cadeia de observadores, cuja interação é forjada primariamente em uma cena, a partir do cruzamento de olhares. A reflexividade seria inerente aos espaços livres como ruas e praças, que se estruturariam mediante tais intersecções. Consideramos válido levar em conta tal orientação para discernir sobre o papel da produção fotográfica na compreensão dos becos recifenses, pois suas imagens representativas se fazem num processo de necessário contato intersubjetivo com a paisagem (estar, observar, produzir). Como resultado prático, esperamos ensejar a diminuição das invisibilidades ali presentes e trazer à tona a importância histórica, econômica e cultural desses lugares para a memória da cidade.

\section{Becos: herança colonial, retratos e vasos comunicantes da vida na cidade}

E por que não falar também dos becos? Afigura-se-me que essas passagens estreitas nasceram de um imperativo de sociabilidade. Comunicações mais curtas e rápidas por necessidades de relações, de visitas, de comércio, de amôres. Ia-se mais depressa por ali, por entre casas. E a passagem como serventia pública persistiu na paisagem urbana. Sua fisionomia, seu préstimo, sua figura popular veio a dar-lhe o nome. Beco da Viração, do Serigado, da Luxúria, do Sarapatel, do Veras, do Calabouço, da Roda, do Quiabo, das Sete Casas... Cada denominação dessas ressalta uma origem. É uma tela, é um retrato. Tem côr, tem cheiro, tem malícia... (SETTE, 1948, p. 16)

Pequenas ruas estreitas onde se concentram as classes menos abastadas, os becos sempre lograram um "papel secundário nos estudos da paisagem urbana recifense” (HALLEY, 2012, p.2), 
ainda que Mário Sette, nos anos 40 do século passado, já indagasse sobre o porquê de não se estudar essas "benéficas passagens", posto constituírem convenientes atalhos que, devido a suas múltiplas utilidades públicas, persistiram na paisagem urbana recifense (SETTE, 1948). Percebe-se uma marcada ambiguidade na maneira como o modesto tipo de arruamento é concebido pela sociedade, o que pode ajudar a explicar os paradoxos que envolvem sua permanência incerta como elemento da morfologia e do imaginário de muitas cidades brasileiras.

Intelectuais e artistas, das mais diferentes partes do país, imortalizaram a expressividade contraditória do beco em suas obras. Por exemplo, na interpretação de poetas, como a goiana Cora Coralina (1980), beco representa uma "paisagem ausente", sendo evocado como algo triste, tão estreito quanto o seu "destino resumido", abandonado, sujo e assombrado, constituindo-se num "lugar de gentinha" e de "mulheres da vida", embora possa ser ao mesmo tempo romântico e pecaminoso, espaço de drama e inspiração, essencial à vida da cidade como meio de circulação. Também para o pernambucano radicado no Rio de Janeiro, Manuel Bandeira (1961), beco remonta às "paixões sem amanhã", pecados, "rua de mulheres", tristezas, sonhos juvenis e lugar dos pobres, o que não impede que seja decantado com carinho, orgulho e nostalgia, um espaço santo apesar de todas as quedas.

Os poucos geógrafos que se debruçaram sobre esse pedaço mais acanhado da urbe também ressaltaram suas dubiedades. Estudando o caso recifense, Bruno Maia Halley considerou que tais logradouros carregariam sentimentos antagônicos, sendo "alvo de depreciações no imaginário da cidade, e, outrossim, de vocações que emanam apego e afeto ao lugar de vivência” (HALLEY, op. cit., p.2), conclusão que fez eco ao verificado em Fortaleza por José Borzacchiello da Silva, para quem a alma daquela cidade em crescimento vertiginoso seria mais forte e genuína em seus becos, tornando-a única e plena de sentidos (SILVA, 2001, p.76).

A capital pernambucana, bem como outras metrópoles que remontam ao tempo colonial, sofre com o estigma que paira sobre os becos, a exemplo de Porto Alegre que foi estudada pela historiadora Sandra Pesavento (2001) ao remontar a construção do ideário histórico espacial de um "mau lugar". Com o intento de percorrer as origens dos becos, que não é a proposta central do presente estudo, Pesavento parte da premissa de serem eles, no final do século XIX e começo do 
$\mathrm{XX}$, espaços de enclave no centro da cidade, relegados à conotação pejorativa. "Nesse momento de fim de século, o beco foi identificado como o reduto das sociabilidades condenadas, era um espaço maldito da cidade, frequentado pelos 'turbulentos' da urbe" (PESAVENTO, 2001, p. 98). Entretanto, em anos anteriores ao momento histórico citado, os becos de Porto Alegre não tinham essa conotação pejorativa e abrigavam moradores de diferentes extrações sociais. Para a referida autora, o momento em que os becos ganham a conotação de mau lugar é no final do século XIX, situação de mudanças urbanas significativas, pois a cidade se expande populacional e territorialmente, passando de 15 mil habitantes na metade do referido século para cerca de 73 mil habitantes em 19004.

A pesquisadora citada se deparou com a primeira referência escrita em Porto Alegre sobre esses espaços em um documento da Câmara datada de 1804, através de um requerimento de termo de propriedade, no qual descreveu-os como 'largos' e limpos e que teriam sido traçados pelo poder público em perpendicular com as ruas principais. A partir daí Pesavento (2001) analisou plantas da cidade entre 1837 e 1888, e considerou ter encontrado uma "pista interessante" que vem a caracterizar morfologicamente e espacialmente os becos como ruas transversais em relação às ruas principais. Essa de fato é a característica mais contundente no sentido de definir a morfologia dos becos do centro histórico, tendo em vista que a largura da via gera confusão no sentido de ter sido encontrado nas plantas da cidade ruas mais estreitas que os becos. Seriam eles vias de ligação entre ruas principais. A autora considerou que os becos identificados são fenômenos definidamente intra-urbano, centrais e de enclave dentro da urbe mais antiga de Porto Alegre. O caráter de enclave está relacionado com os becos do final do século XIX, quando eles se tornam lócus da população mais pobre do centro.

Assim como mostrou a pesquisa de Pesavento, os becos objeto do presente artigo estão situados num espaço de centralidade histórica e urbana da cidade do Recife e apresentam a mesma característica de transversalidade. $\mathrm{Na}$ história de ocupação territorial desse espaço, que começou pela estreita faixa de terra rente à desembocadura do rio Capibaribe, hoje Bairro do Recife, já temos notícia da presença de ruas estreitas e becos. Segundo estudos de Mota Menezes, a organização do povoado do Recife possuía um desenho simples decorrente da disponibilidade de terras para construção, 
onde "as casas, armazéns e a ermida foram distribuídos em linha, isto tendo uma rua por eixo. Um largo com uma ermida e ruelas transversais. Becos muito estreitos e ruas hierarquizavam e caracterizavam o tecido urbano." (MENEZES, 2015, p. 4).

Com a presença holandesa de 1630 a 1654, a ocupação territorial de caráter urbana seguiu mais para o continente com um plano urbanístico para a ilha de Antônio Vaz, onde hoje temos os históricos bairros de São José e Santo Antônio. Perspectiva diferente de organização do espaço das cidades dos portugueses, os flamengos imprimiram à área ocupada um traçado retilíneo e monumental, fruto de uma tendência moderna renascentista europeia baseada numa ordem geométrica e racionalista (REZENDE, 2002). Depois da saída dos holandeses, a tradição urbanística portuguesa voltou à baila. Assim, temos ao longo dos séculos XVIII e XIX, atrelado ao aumento populacional nesse período, em que Recife passa de 26.000 habitantes, em 1810, para 70.000 em 1850 (MENEZES, 1993), o surgimento de uma cidade de becos e travessas, ruas estreitas e pátios de igrejas.

Em análise do mapa do Recife de Douglas Fox, do ano de 1906/07, constatamos que os becos e travessas estavam concentrados tanto no Bairro do
Recife como na Ilha de Antônio Vaz nas porções de terras ao sul. $\mathrm{Na}$ citada ilha, esse espaço meridional, que compreende o bairro de São José, foi planejado no período holandês para abrigar as pessoas menos providas de capital.

\begin{abstract}
Nassau projetou construir, também, um bairro para os habitantes mais pobres da cidade: parece que essa era a finalidade de seu projeto pois os documentos se referem a essas construções chamando-as de "casinhas". Esse bairro estava localizado entre o canal que desembocava em frente à Barreta (ao lado da Igreja Francesa) e o Forte das Cinco Pontas (MELLO, 2001, p. 93).
\end{abstract}

Com isso, o bairro de São José começou numa trajetória de um espaço destinado às populações mais pobres. Espaço com parcelamento do solo intenso, residências de planta baixa simples e insalubres, o traçado das ruas se afinou com a população ali residente, carente de espaço e de recursos para viver melhor. Essa configuração do século XVII gerou uma estratificação social do espaço da Ilha de Antônio Vaz que se expressou, no período holandês, como área residencial popular ao sul (coincidente com o bairro de São José), centro de atividades comerciais em torno da praça do Polé 
(hoje Praça da Independência, conhecida como pracinha do Diário, no bairro de Santo Antônio), e o poder político ao norte da ilha (bairro de Santo Antônio) (REYNALDO, 2017).

Nos anos 1930, quase 300 anos depois, o contexto de estratificação social do período holandês ainda persistia, segundo Amélia Reynaldo (2017), ao estudar o ordenamento urbano dessa área central do Recife. Ao mesmo tempo, nessa mesma década, as redes ferroviárias e os bondes elétricos fizeram o papel de tornar o espaço em questão um centro distribuidor de acessibilidade, o que mais tarde viria a impulsionar as atividades de comércio e serviços nos bairros de Santo Antônio e partes de São José, consolidando a centralidade urbana da área.

Ao longo do século XX, atrelado ao movimento de aprofundamento da centralidade urbana que segue com o processo de transformação do Recife em cidade moderna, o seu espaço de gênese passou a exigir um tratamento de centro antigo, que segundo Amélia Reynaldo (2017) se baseou na acentuada concentração de edifícios singulares, principalmente o Sobrado frente aos novos e modernos standards de edificação. A partir da década de 1970, principalmente com o Plano de Preservação de Sítios
Históricos (PPSH) de 1979, o tratamento das áreas históricas passa de intervencionista a normativo (idem).

Segundo Larissa Menezes (2015), essa mudança de postura não agregou a questão do uso habitacional e da necessidade de contemplar os habitantes ainda existentes nos planos desenvolvidos. E, acrescentamos, que possivelmente não tenha havido interesse por parte da administração pública em garantir a permanência dos moradores, tendo em vista que era a população pobre e preta, marginalizada, que habitava majoritariamente o bairro de São José. A desvalorização - tanto do espaço como dos seus habitantes - se mostra no discurso dos urbanistas; como exemplo citamos o engenheiro paulista Prestes Maia, autor do plano de avenidas de São Paulo, convidado pelo então prefeito do Recife em 1936, que ao tecer análise sobre o centro considerou ser o bairro de São José a área mais deplorável da cidade, com ruas estreitas, habitações velhas, sujas e insalubres (REYNALDO, 2017). Tal desprestígio também se revela em imagens: ao analisarmos o acervo iconográfico capturado por fotógrafos a serviço da Prefeitura do Recife, que está sob a curadoria do Museu da Cidade, contendo em torno de 10.000 fotografias dos anos 1920, 1930, 1950 e 1970, 
encontramos apenas três imagens dos becos.

Por fim, há uma discriminação toponímica, que se expressa histórica e contemporaneamente na modificação da nomenclatura de algumas vias, que passam de beco para travessa ou rua. Segundo o historiador Leonardo Dantas, o beco "Tornou-se uma denominação em desuso por parte da própria Prefeitura do Recife, que preferiu denominar os tradicionais nomes em Rua Doutor Fulano de Tal” (JORNAL DO COMMERCIO, 2013). Conforme Raimundo Arrais (2004 apud HALLEY, 2012, p.7), a prática do poder municipal de mudar os nomes de ruas e becos no Recife iniciou-se já em meados do século XIX, com o objetivo de adaptar a cidade aos ditames do progresso, numa verdadeira "reconversão toponímica” do espaço público. Halley sublinha que becos cujos nomes não condiziam ao sentido do "próprio nacional" tiveram que mudar de alcunha a partir de 1866, inclusive devido à ação do recém-criado Instituto Arqueológico e Geográfico Pernambucano.

Como quer que seja, o comércio e os serviços antes concentrados no bairro de Santo Antônio e timidamente na franja fronteiriça deste com o bairro de São José, especialmente nas adjacências do mercado de São José, desenvolveram-se em detrimento da habitação, transformando a espacialidade dos usos numa parte da cidade que guarda marcas da identidade recifense. Nesse ínterim, alguns becos, cujo espaço era das habitações mais precárias e das pessoas mais marginalizadas da sociedade (como as prostitutas) consolidaram-se funcionalmente como passagens e atalhos, permitindo um intenso fluxo de pessoas entre as ruas principais. Tornaram-se também espaços de vivo comércio e serviços, inclusive de ambulantes que, sem capital para manter o aluguel de um imóvel, se apropriam desse espaço público. Assim, nos dias de hoje, no período diurno que contém a dinâmica comercial e de serviços, a imagem com a tônica de mau lugar esmaeceu, pelo menos parcialmente.

Enfim, os becos são uma herança social e espacial colonial, caracterizados como vias transversais de ligação entre ruas principais, lócus da sociabilidade dos mais pobres, ocultados pela administração pública e, transformados em espaço intenso de compras, serviços e fluxos. A partir dessas premissas nos mobilizamos para realizar a aproximação do objeto in sito, privilegiando a atitude in visu, a partir da chave conceitual paisagem, num percurso investigativo alicerçado no fazer fotográfico. 


\section{Paisagem entranhada: um outro ponto de vista}

Da janela do meu quarto em Morais e Vale podia eu contemplar a paisagem, não como fazia do morro do Curvelo, sobranceiramente, mas por dentro dela $[\ldots .$.$] era o becozinho sujo:$ embaixo, onde vivia tanta gente pobre.

(BANDEIRA: 1996, p.81).

Ao propormos a questão da contemplação, valorização e registro de uma paisagem não-panorâmica, consideramos ser a imagem e o imaginário elementos importantes na compreensão da geografia dos becos. Pensar por este caminho nos aproxima da construção identitária de um espaço recôndito e, ao mesmo tempo, nos auxilia no próprio descortinar do objeto de pesquisa em questão. Portanto, ao contrário de outras incursões relacionando fotografia e paisagem (MACIEL; VASCONCELOS, 2016), desta feita colocamos em sursis a conotação ampla e totalizante do olhar comumente pressuposta por esse conceitochave.

No sentido do apelo ao visual e imaginário, mobilizamos o conceito de paisagem, posto que se trata de uma das ferramentas de análise geográfica que melhor possibilitam o reconhecimento simultâneo dos aspectos objetivos e subjetivos da realidade. Através da paisagem, a geografia tem buscado abarcar o senso ou saber humano total (formal e ordinário) do espaço em diversas perspectivas teóricas (MACIEL, 2004, p.66). De um ponto de vista interpretativo, e à luz do imaginário social, o senso paisagístico permite uma abertura às cosmovisões dos outros, as quais tornamse objetos privilegiados não só para a análise, mas também para as trocas de saberes. Como afirma Bernard Debarbieux "de uma maneira geral, a alteridade é fonte de imaginário. O alhures é antes de tudo uma imagem" (DEBARBIEUX, 1995, p.879).

Todas as sociedades pensam sua relação cotidiana com o espaço, o que torna possível à geografia aceder a esses saberes culturais mediante a expressividade da paisagem e sua razão metonímica (MACIEL, 2004; 2009). O seu potencial retórico metonímico reside na identificação, eleição e reprodução de geosimbolismos eloquentes, na escolha de cenários e de argumentos descritivos que visam partir do visível para chegar a um "como ver" específico, de modo intencional ou pela força do hábito. Neste sentido, o beco será mais eleito como geossímbolo pela praxe dos sujeitos que ali frequentam 
do que de modo intencional através, por exemplo, de políticas públicas que propaguem esse espaço como uma das imagens ícones do ambiente patrimonializado.

O conhecimento geográfico popular reflete-se na construção de paisagens integrativas ou excludentes face à um território vivido, como no caso do Centro Histórico do Recife, concebendo-se os diversos espaços da existência num mosaico imperfeito que materializa a consciência, a imaginação e a experiência de seus habitantes em correlação com o contexto cultural englobante. A imagem social e espacial dos becos, como não poderia deixar de ser, é "recheada" de idiossincrasias, mas resulta ainda da reflexividade inerente aos espaços públicos (GOMES e RIBEIRO, 2013). Desenha-se um esboço cotidiano da vida a partir de uma localidade constrita, incluindo como pontos de referência objetos, formas urbanas e territórios simbólicos carregados de valores e sistemas de crenças por aqueles que habitam, usam ou passam por suas fendas.

Isto é, as imagens das ruelas do Recife e sua reputação estão impregnadas desses pensamentos e saberes visuais entrecruzados pela população. Como toda percepção é necessariamente fragmentada e parcial, "tudo dependerá do lugar de onde observamos e da direção e foco do olhar, em suma, do ponto de vista" (GOMES e RIBEIRO, 2013, p.31). E o ponto de mirada do beco, como temos buscado demonstrar, é bastante peculiar e orientado por sua natureza fissural e absconsa. Ao propormos o ponto de vista da paisagem do beco, elegemos uma moldura, uma escala e um modo de compor. Tal escolha "é uma colocação em relação das coisas que estão juntas, enquadradas e que produzem sentido uma vez que estão associadas pela posição no espaço" (idem, p.32).

Entretanto, na paisagem cultural das cidades, as imagens panorâmicas e fotografias postais de espaços icônicos é que cumprem, comumente, o papel de representantes geossimbólicos de primeira ordem, posto que buscam transmitir uma ideia de conjunto, facilitando o reconhecimento e a identificação de uma fisionomia própria e integral dos lugares. Como lembra Mota Menezes (2011, p.199), já as primeiras imagens fotográficas do Recife buscavam espaços amplos a partir de uma visão de cima para baixo, em um modelo que consagrou certo enquadramento e leitura do espaço. Ainda sobre o panorama na fotografia, afirma Sérgio Burgi: 
A fotografia se alinhava às formas de representação visual já estabelecidas e consagradas, como o desenho, a pintura e a gravura. [...] Esse processo, inicialmente, associou a prática fotográfica à descrição figurativa e ao tempo histórico, ressaltando assim suas funções documentais e memorialísticas. Essas características seriam objeto de crítica e negação pela fotografia contemporânea e moderna (autoral) e pós-moderna (conceitual) do século $\mathrm{XX}$, após o esgotamento, no século XIX, de sua função documental na época absolutamente revolucionária e moderna (BURGI, 2012, p. 47-48).

Por outro lado, espaços mais recônditos e carregados de intimidade, como os becos e arruados, também integram a alma de algumas cidades, muito embora sejam relativamente de difícil estampa ou induzam a pontos de vista inusitados. O lugar do olhar a partir de uma rua estreita muda as possibilidades da integração entre o adentro e o afora, seja do ponto de vista da materialidade espacial ou das impressões da alma sobre a cidade. A fotografia moderna e autoral pode privilegiar, assim, miradas e perspectivas em outras escalas e aproximações.
Nara Boneti Foresti (2000), ao analisar no "Poema do Beco" o contraste entre o que oferecia a janela ao poeta Manuel Bandeira - o esplendor de ícones da paisagem do Rio de Janeiro: a baía da Guanabara, o bairro da Glória - e o que os olhos dele notavam na estreiteza de uma viela da Lapa, destaca também essa condição contraditória do espaço que aqui buscamos refletir, a qual pode corresponder a diferentes estados de espírito:

[...] o beco retém o poder de significar ao mesmo tempo um "dentro" e um "fora": na cidade, toma o lugar de um quarto fechado pelas paredes das construções, se põe como espaço interior; na presença da rua, o beco é o exterior. Mas, o importante é que ele, o beco, nunca é um só espaço, mas sim a tensão entre eles, o dentro e o fora ao mesmo tempo (FORESTI, 2000, p.152, grifo nosso).

A tensão entre cerne e frontispício também pode corresponder a diferentes dimensões da paisagem dos bairros aqui estudados, com suas travessas e ruas históricas. Integrando uma janela peculiar, os becos possibilitam uma associação específica entre os ambientes semifechados e abertos que compõem o espaço público. 
Em suma, como representar e discutir a paisagem de espaços fissurais e "sem uma ampla fachada" como os becos? Uma das saídas é aceitar, com BeyaertGeslin (2005) que, acima de tudo, paisagem é um conceito muito mais complexo do que panorama - e, portanto, a paisagem de espaços recônditos e obstruídos como os becos não cabe numa abordagem panorâmica, convencional e redutora.

Se o verbo contemplar aproxima paisagem e panorama, os espaços de difícil contemplação totalizante solicitam outras entradas, que não a de uma vista englobante e representativa de um vasto conjunto, como tem sido comum no "regime escópico" dominante. Ulpiano Meneses ressalta que tais regimes seriam modelos de apreensão de coisas, processos e eventos que permitem investigar a visualidade, ou seja, o conjunto de discursos e práticas que constituem distintivas formas de experiência visual, historicamente circunstanciadas (MENESES, 2003, p.22 e 31). No caso do espaço em questão, o padrão de visualidade do sítio tombado de São José e Santo Antônio considera desimportante quando não ausente - a representação pictórica dos seus becos e vielas.

Os geógrafos, um pouco pela força do hábito com suas origens no século XVI com a paisagem bruegheliana e a cartografia 'mundi', na qual a paisagem ganhou o caráter de 'teatro do mundo' e para entende-la dever-se-ia se afastar ou se elevar (BESSE, 2006), tenderam a fazer corresponder o panorama à paisagem. Entretanto "se o uso tende a associar paisagem e contemplação, a percepção da paisagem não se resume apenas a este modelo que engendra uma estratégia abrangente, que busca a totalidade [...] supondo uma visão distante e um acesso sem entraves" (BEYAERT-GESLIN, 2005, p.70).

Num movimento para além da escala tradicional de uma geografia da paisagem contemplativa, prossegue a autora, apoiando-se em Ouellet (2000) e Fontanille (1999), com a ideia de que a paisagem não é necessariamente contemplada como num panorama, podendo muito bem ser imaginada e delineada a partir de horizontes mais estritos, de outras escalas. Imaginar e esboçar a paisagem seriam atos correspondentes a apreciar um cenário distanciado, só que fornecido por um acesso difícil e obstruído: uma paisagem decorrente da "maneira pela qual uma vista se deixa discernir (visão de perto; acesso difícil, obstruída), examinar (visão de perto, de fácil acesso, sem obstáculos) e, de forma mais simples, ver ou assistir, dois 
verbos que, de forma diferente, traduzem uma neutralidade de acesso ou de distância” (Idem).

Portanto, a espacialidade própria dos becos e suas possibilidades de representação na chave da paisagem nos levam a problematizar a relação - tida como óbvia na geografia - entre panorama e contemplação, buscando tentativas de resposta desenhadas pela fotografia.

\section{O descortinar não panorâmico a partir} da experiência fotográfica: aberturas para problemas-imagéticos

Ao realizarmos o percurso de investigação imagética, traduzindo-a textualmente no presente artigo, buscamos apontar novas possibilidades de se pensar a geografia dos becos, incluindo pontos de vista mais nuançados acerca de sua natureza complexa. Somente conseguimos chegar a tais reflexões e proposições imaginadas e narradas a partir do esforço de pensar com as imagens. As imagens como fontes/dados para a compreensão dos becos foram buscadas em formato de narrativa textual, mapas, fotografias históricas (Acervo do Museu da Cidade) e fotografias autorais.

Numa miscelânea de ordem imagética, destacamos o interesse metodológico nas fotografias autorais por considerá-las ferramentas tão potentes como os mapas, já consolidados no métier da pesquisa geográfica. Imergimos no contato com os becos ao longo de seis trabalhos de campo no Bairro de São José, entre 2015 e 2016. Durante este período, ensaiamos produzir fotografias da área patrimonializada sob pontos de vista nãoconvencionais, na busca de refletir acerca da construção dos modelos de visão dos becos.

Muito mais do que propor respostas, levantamos questões que expressam-se em "problemas imagéticos" ou quebra-cabeças iconográficos que podem ser considerados para a análise de outros espaços que não se apresentam necessariamente como panorâmicos. Os quadros aqui trabalhados incitam-nos a remontar como as espacialidades dos becos podem ser retratadas, muito mais do que ilustradas por exemplos estanques, como costuma acontecer em tantos trabalhos de geografia.

\section{Caso I}

Consoante mencionado em tópico anterior, ao buscarmos a herança colonial do espaço em questão, nos deparamos com três fotografias realizadas, nos anos 50 , no âmbito da administração pública dos seguintes becos: 1. Beco do Viado Branco de São José, de 1956, foto de Severino 
Fragoso; 2. Beco do Sirigado, de 1958, foto de Cisneiros; 3. Beco do Marroquin, anos 1950, foto NDI. Percebe-se nelas um afastamento dos sujeitos do território retratado e o interesse pelo traçado urbano visto de fora. Apresentam similitude por ângulos e perspectivas na altura do "olhar humano", e tentam enquadrar os becos na abordagem da paisagem panorâmica. A estratégia escolhida para ensejar o panorama pretendido revela-se nas fotografias $1 \mathrm{~A}$ e $1 \mathrm{~B}$ ao retratar os becos de fora para dentro, a qual prescinde de maior amplitude e profundidade - uma busca pelo horizonte. Escolha estratégica que leva a uma pretensa conotação de neutralidade e distanciamento, como explícito na fotografia $1 \mathrm{C}$ na qual a mirada da foto foi de dentro do beco, contudo, em sua contingência, a foto expressa a tensão de se buscar um fora estando dentro.

Pelo olhar distanciado do registro oficial impera um senso comum de becos como ruelas sem muita expressão no conjunto da cidade, fato denotado na própria quantidade de fotos do espaço em questão no acervo. Contudo, a importância de partirmos deste tipo de pictorialização dos becos deve-se à necessidade de se considerar o regime escópico que possibilitou - e, de certa maneira, continua a possibilitar - a construção de tais representações espaciais. E, principalmente, sugere para a pesquisa outras entradas visuais para compreendermos essa paisagem entranhada a partir de seu próprio âmago.

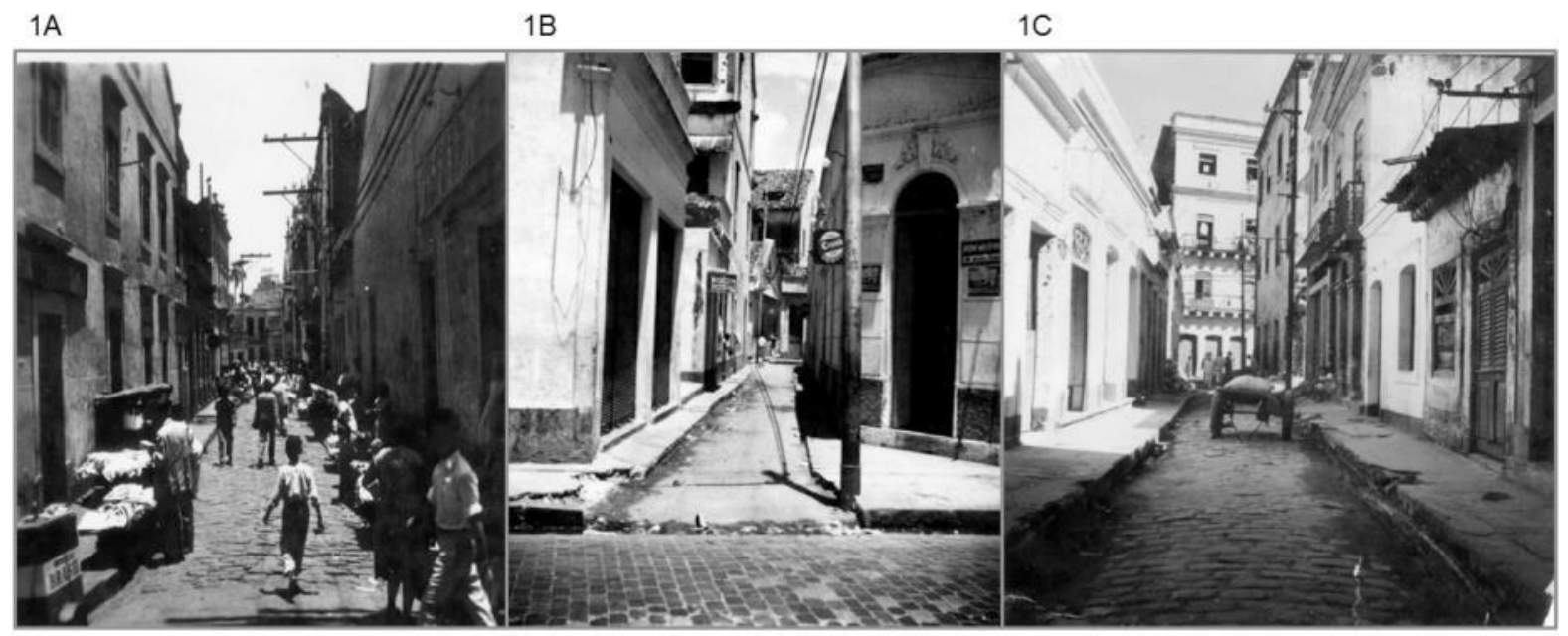

Figura 1: Becos do São José, anos 1950 (Fotos: Acervo do Museu da Cidade do Recife, 2016.) 
Caso II

$\mathrm{Na}$ realidade das três fotografias colocadas no caso I temos instantes congelados do cotidiano e das coisas, situação exposta, mesmo que talvez não pretendida pelo testemunho dos fotógrafos (KOSSOY, 2014), que colabora com o entendimento das espacialidades dos becos. Por isso, antes de nos colocarmos dentro da janela dos becos, adentramos no procedimento de produção de fotos autorais tentando tecer algumas comparações com os espaços identificados nas fotos antigas: os mesmos becos em outra temporalidade expressos na figura 2 . Inferem-se, então, grandes diferenças na organização do espaço, ao mesmo tempo em que se desnudam alguns impasses resultantes dos artifícios panorâmicos mobilizados no passado para retratar aqueles (maus) lugares. A marcante presença de pessoas e objetos que obstruem a visão, no presente, rebatem a pretensão de se tomar uma mirada de conjunto em cada viela, ao mesmo tempo em que sugerem a imersão, aproximação e a bricolagem de pontos de vista como uma estratégia alternativa e mais eficiente. Dito de outra maneira, os becos hoje dificilmente se encaixam em representações panorâmicas, a menos que sejam evacuados de homens e coisas. Por conseguinte, levanta-se a questão: como espaços tão densos e vivamente frequentados podem ser tão pobres de registros iconográficos públicos?

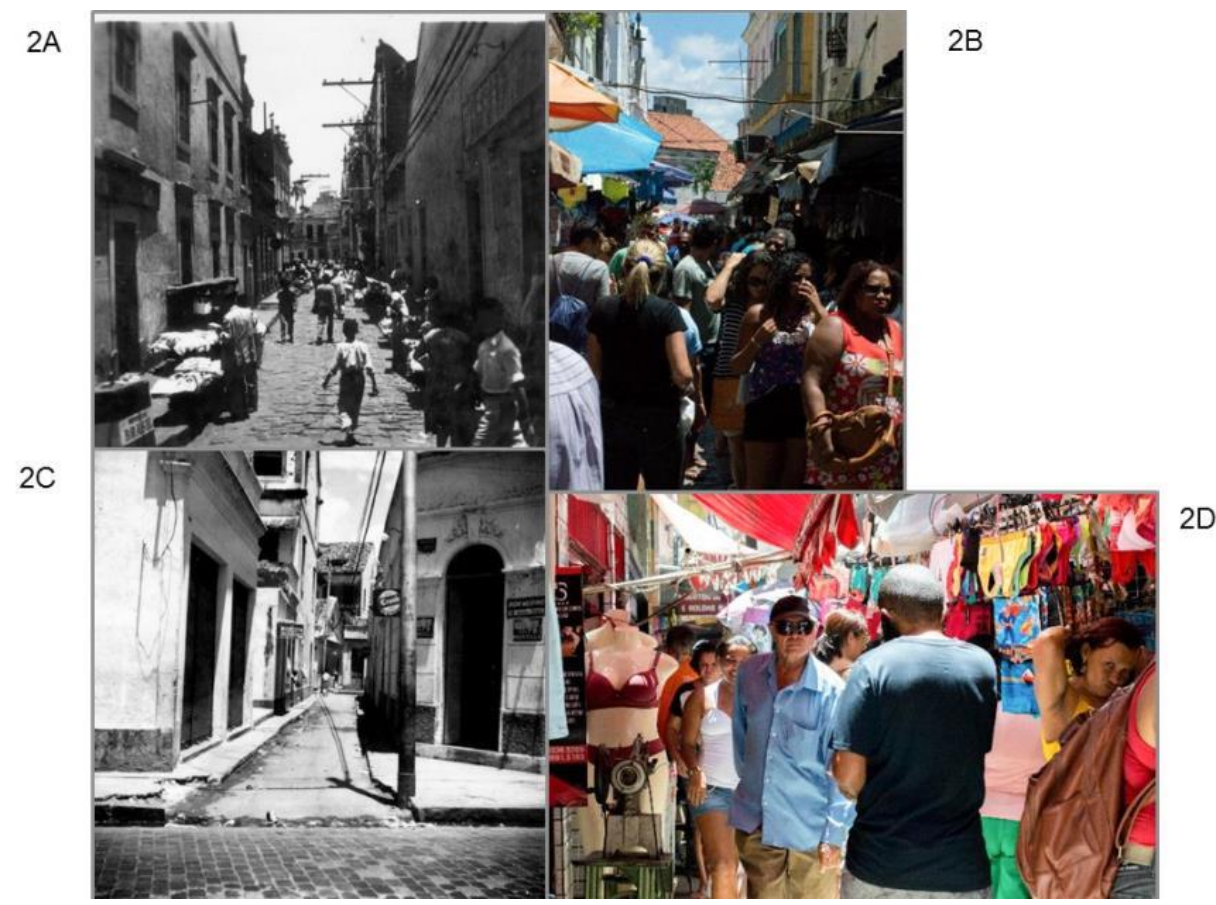

Figura 2: Comparação espacial-temporal entre os anos 1950 e 2016 dos Becos do Veado Branco (2A e $2 \mathrm{~B})$ e do Sirigado (2C e 2D). (Fotos: Acervo do Museu da Cidade do Recife; Priscila Vasconcelos e Caio Maciel, 2016). 


\section{Caso III}

Ainda na perspectiva do olhar "de fora para dentro", nos demos conta da condição de imperceptibilidade atual de alguns becos ao fotografar o processo de entrada nos mesmos, explícito na figura 3. Espaço que abriga simultaneamente um campo de fora (visibilidade obstruída) e um campo de dentro (visibilidade aproximada). Ao penetrá-los o sujeito vivencia a proximidade de corpos que incita à perceptibilidade de muitos elementos “por dentro da paisagem”, como cogitou Manuel Bandeira (1996), e a uma sociabilidade assaz diferente das de ruas, pontes, praças ou largos. Assim, a tensão entre observar e estar na paisagem (WYLIE, 2007) é fato marcante e quase que inevitável neste tipo de espaço, cuja limitada amplitude de ângulos possíveis de observação oferece um enquadramento mais bitolado e uma experiência de presença em relativa reclusão.

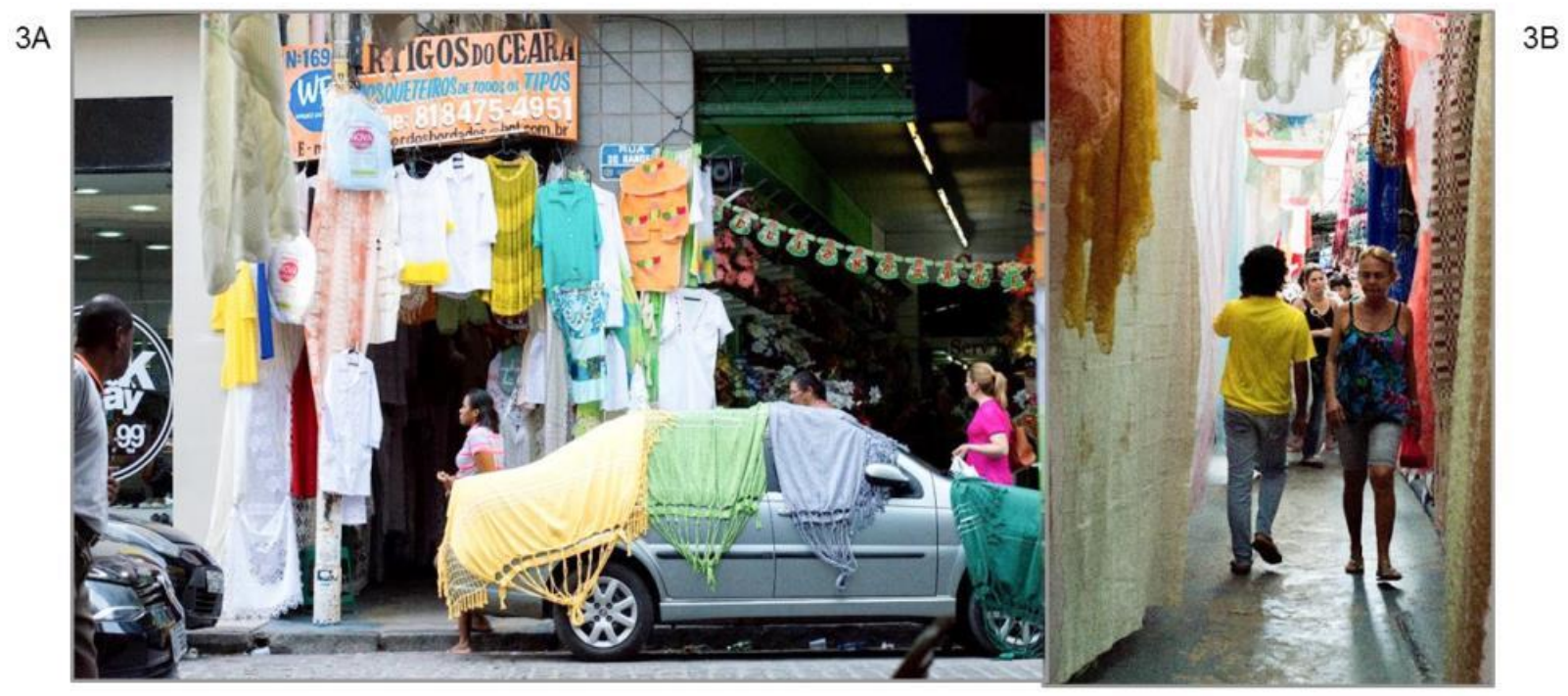

Figura 3: Um campo de fora (visibilidade obstruída - 3A) e de dentro (visibilidade aproximada - 3B). (Fotos: Priscila Vasconcelos e Caio Maciel, 2016) 
Caso IV

Os problemas mais gerais apresentados nos casos anteriores precisam ser complementados pela verticalidade da luz e estreiteza de planos no interior das vielas. A partir de agora, no campo de dentro, propomos outros olhares expressos na figura 4 e 5, como reveladores das condições da experiência de estar e representar becos, incorporando o incidental, as réstias de luz, o incomum e inabitual que o confinamento daqueles espaços solicita de nossos sentidos e sentimentos. De fato, os becos se configuram como um espaço fissural que, em algumas situações, nos remetem a um canyon ou o interior de uma floresta tropical, cujos feixes de luz entram a partir de brechas deixadas entre as tendas dos ambulantes erguidas ao longo do trajeto.

Espaço confinado, por vezes topofóbico, por, além de se configurar como um lugar de frestas, ser densamente ocupado/usado, o que confere uma trama de territórios fixos e também fluidos, de tempo longo e também instantâneos. Espaço entranhado e íntimo porque induz ao transeunte e aos sujeitos que ali trabalham a estarem muito próximos dos olhares, odores, ruídos e corpos uns dos outros, como sentido na figura 5. Espaço público onde a proximidade é um imperativo.

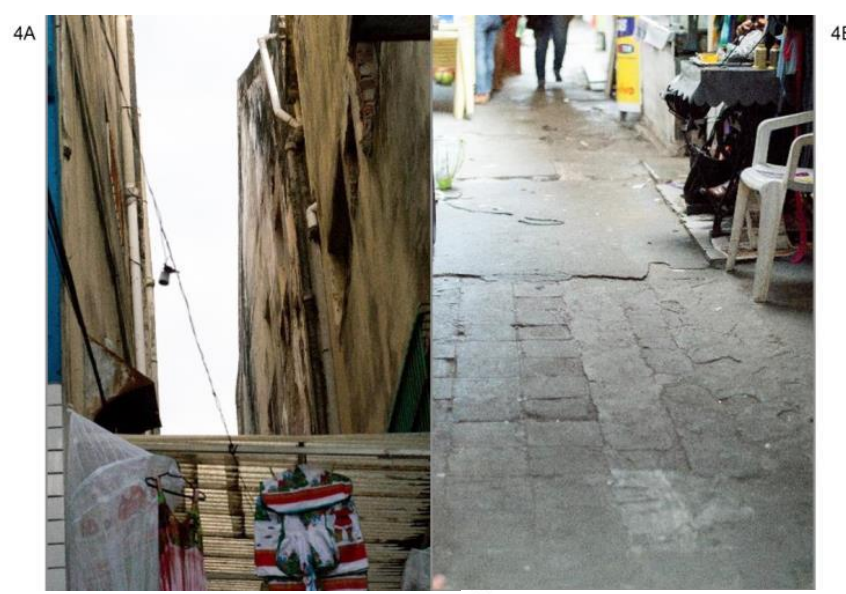

Figura 4: 'Olhar' para cima e 'Olhar' para baixo. (Fotos: Priscila Vasconcelos e Caio Maciel, 2016).
$5 A$

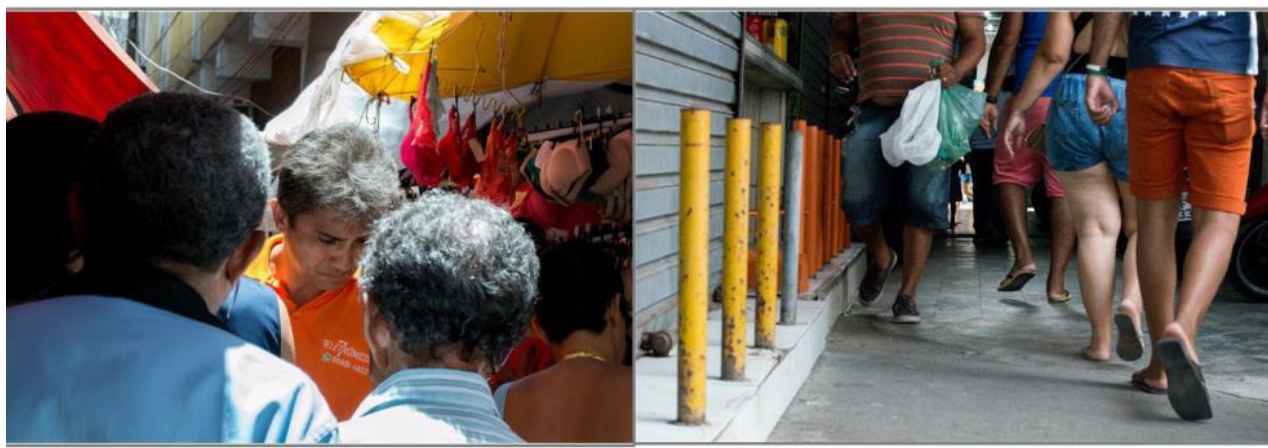




\section{Considerações finais}

Apesar da importância na cultura comercial e na história do Centro Histórico do Recife, os becos não fazem parte da iconografia simbólica da cidade, fato que pode ser facilmente exemplificado pela dificuldade de encontrar ou imaginar quais seriam as fotografias icônicas das nossas vielas.

É provável que isto tenha a ver com a história espacial dos becos ligada às populações pobres e negras que, na cultura visual urbana brasileira, foram relegados aos espaços invisibilizados. Ambientes pouco aparentes, sujos, depauperados, perigosos, tal qual “entranhas” do espaço público, no sentido de elementos comunicantes em partes labirínticas e intricadas das cidades. Por outro lado, revela-se a contradição de que as ruelas perfazem ainda hoje aquelas conexões mais curtas e rápidas entre os logradouros de que fala Mário Sette (1948, p.16), "por necessidades de relações, de visitas, de comércio, de amores".

Para o transeunte ou o comerciante a paisagem dos becos é uma bricolagem, dificilmente um panorama, mas sim um quebra-cabeça montado na sua presença, no ato de passar por ele ou ali estar, com todas as suas limitações de distanciamento, obstáculos e dificuldades de pontos de vista. Paisagem angular, marcada pela verticalidade da luz, um objeto visível, porém poli sensorial, onde o sujeito (seja passante ou plantado no lugar) necessita fazer um exercício coerente de "montagem" de suas inúmeras partes, as quais nunca se apresentam em conjunto.

Tal sugestão de procedimento metodológico para refletir sobre cenários não-panorâmicos nos remetem, novamente, à inspiração de Gomes e Ribeiro (2013, p.34) quando afirmam haver uma "pedagogia de educação visual geográfica”, capaz reafirmar a experiência de "pensar com as imagens". O regime de visibilidade (GOMES, 2013) dos becos é bastante específico, assim como as possibilidades de torná-los perceptíveis de modo mais adequado ao seu melhor ajuste em políticas de patrimonialização.

Dito de outra maneira, se as imagens dos becos são artefatos que nos permitem revelar determinadas coisas sobre o Recife, sobretudo a pouca visibilidade dos seus "maus lugares", como a produção fotográfica de novos ângulos, pontos de vista e composições podem alterar as próprias condições que regulam nossa percepção sobre a espacialidade do seu Centro Histórico? Ao refletir sobre formas, funções, eventos e processos inerentes à geografia dessas travessas, 
tentamos dar conta, imageticamente, de suas qualidades materiais e sociais intrínsecas: estreiteza, profundidade, vista obstruída, verticalidade de luz, proximidade corporal, rota de atalho com intenso movimento, dentro/fora, lócus de comércio e serviços etc. Ora, são tais condições que explicam, em grande parte, que num regime escópico dominante, o qual privilegia a paisagem panorâmica, os becos permaneçam apagados da iconografia geossimbólica. Apenas se aceitarmos e contemplarmos as morfologias, funcionalidades e naipes inerentes à espacialidade das vielas poderemos repensar maneiras de representá-las e integrá-las à fisionomia iconográfica dos bairros históricos do Recife.

Assim, esperamos contribuir para desvelar as imagens dos becos do centro recifense, produzindo uma reflexão a partir de e com base na produção de fotografias sobre estes eixos de fluxos tão vitais para a manutenção dos espaços patrimonializados, embora pouco integrados a uma imagem representativa do seu sítio histórico. Num sentido que supera o estudo de caso, pretendemos ter contribuído para a reflexão sobre as relações entre paisagem, contemplação e panorama através de práticas oriundas da arte de fotografar os espaços públicos mais exíguos e entranhados da cidade, superando posturas que tendem a reduzir aqueles conceitos e concepções a sinônimos patentes ou auto evidentes.

\section{NOTAS}

* Geógrafa e bolsista pós-doutoral CAPES/PNPD, pelo Programa de Pós-Graduação em Desenvolvimento Urbano da Universidade Federal de Pernambuco- UFPE. Doutora em Geografia pela UFPE. Pesquisadora do Laboratório de Estudos sobre Espaço, Cultura e Política (LECgeo), em Recife.

** Geógrafo e professor da Universidade Federal de Pernambuco (UFPE) onde conduz estudos sobre região, paisagem e espaço público. Doutor em Geografia pela Universidade Federal do Rio de Janeiro (UFRJ), realizou estágio pós-doutoral na Universidade de Sussex, Reino Unido. Coordena desde 2008 o Laboratório de Estudos sobre Espaço, Cultura e Política (LECgeo), em Recife.

1 A pesquisa intitula-se "Funcionamento do mercado imobiliário nos centros históricos das cidades brasileiras", sob a coordenação da Professora Titular do Departamento de Arquitetura e Urbanismo e do Programa de Pósgraduação em Desenvolvimento Urbano (MDU/UFPE), Norma Lacerda. Esse projeto envolve os centros históricos das seguintes cidades brasileiras: Recife e Olinda (PE), Belém (PA) e São Luís (MA). Financiada pelo CNPq/Capes.

2 "Após o incêndio de Olinda, em 1631, o Recife deixa de ser apenas um porto e torna-se o centro político do governo holandês no Brasil: torna-se a Cidade Maurícia ou Mauritsstad.” (PONTUAL, 2001). "Na ilha de Antonio Vaz, o intervencionismo urbanístico incentivado por 
Nassau transformou a paisagem canalizando os braços de rio, aplainando o terreno e fazendo erguer-se a Cidade Maurícia.” (BREDA, 2007).

${ }^{3}$ No Centro Histórico do Recife incide legislação preservação do patrimônio inscrito como 'Zonas Especiais de Preservação do Patrimônio HistóricoCultural', definidas pela Lei de Uso e Ocupação do Solo - LUOS (Lei $n^{\circ}$ 16.176/1996): A área de estudo do presente artigo compreende a ZEPH 10 - Bairros de Santo Antônio e parte do Bairro de São José.

4. "Em termos propriamente urbanos, houve um aumento da população na área central e uma expansão do perímetro urbano, incorporando o que até então eram subúrbios e arraias. Os terrenos se valorizam, e os investimentos imobiliários se incrementam a partir da disponibilidade de investimento daqueles que dispõem de recursos. Como já se viu, havia a prática de alguns capitalistas da praça de construírem habitações modestas para fins de aluguel nas novas vias públicas que se abriam, como no caso dos becos. Provavelmente os sobrados e casas de maior porte que lá existiam foram abandonados por seus moradores e sublocados a novos inquilinos, devido a população de baixa renda que aumentava." (PESAVENTO, 2001, p. 115).

\section{REFERÊNCIAS BIBLIOGRÁFICAS}

ARRAIS, R. O pântano e o riacho: a formação do espaço público no Recife do século 19. São Paulo: Humanitas/FFLCH/USP, 2004. (Série Teses).

BANDEIRA, M. Antologia poética. Rio de Janeiro: Editora do Autor, 1961.

Aguilar, 1996

Poesia Completa e Prosa. Rio de Janeiro:

BEYAERT-GESLIN, A. Le panorama, au bout du parcours. Protée, vol. 33, n 2 , 2005, p. 68-78.
BERNARDINO, I. L.; LACERDA, N. Centros históricos brasileiros: tensões entre a obsolescência imobiliária e a construção de novas espacialidades. Revista Brasileira de Estudos Urbanos e Regionais, vol. 17. $\mathrm{n}^{\circ} 1$, abril de 2015, p.61-74.

BESSE, J-M. Ver a terra: seis ensaios sobre a paisagem e a geografia. São Paulo: Perspectiva, 2006.

O gosto do mundo. Exercícios de paisagem. Rio de Janeiro: EdUERJ, 2014.

BREDA, D. O. Vicus Judæorum: Os judeus e o espaço urbano do Recife neerlandês (1630-1654). Natal: Dissertação. (Mestrado em História) Programa de Pós-Graduação em História, Centro de Ciências Humanas, Letras e Artes, Universidade Federal do Rio Grande do Norte. 2007.

BURGI, S. O panorama na fotografia brasileira oitocentista. In: Kovensky, J. (org.) Panoramas. A paisagem brasileira no acervo do Instituto Moreira Salles (Catálogo), Rio de Janeiro, 2012, p.47-61.

CORAlinA, C. Poemas dos becos de Goiás e estórias mais. $3^{\text {a }}$ Ed. Goiânia: Editora da Universidade Federal de Goiás, 1980.

DEBARBIEUX, B. Imagination et imaginaire géographique. In : BAILLY, A.; FERRAS, R. ; PUMAIN, D. Encyclopedie de Géographie. Paris: Economica, 1995, p.875-888.

FONTANILLE, J. Sémiotique et littérature. Essais de méthode, Paris, PUF, 1999.

FORESTI, N. B. Dos espaços poéticos em Manuel Bandeira: o beco. Anuário de Literatura 8, 2000, p.137-156.

GOMES, P. C. C., RIBEIRO, L. A produção de imagens para a pesquisa em geografia. Espaço e Cultura, UERJ, Rio de Janeiro, $\mathrm{n}^{\circ}$ 33, p.27-42, jan./jun, 2013. Disponível em:

$<\quad$ http://www.epublicacoes.uerj.br/index.php/espacoecultura/arti cle/view/8465>. Acesso em: 15 outubro de 2016.

JORNAL DO COMMERCIO (Jornal). Becos costumavam receber nomes curiosos. 06/04/2013. Disponível em:

http://jconline.ne10.uol.com.br/canal/suplemento s/arrecifes/noticia/2013/04/06/becoscostumavam-receber-nomes-curiosos-78852.php Acesso em: 31 de maio de 2017. 
KOSSOY, B. Fotografia e história. São Paulo: Ateliê Editorial, 2014

HALLEY, B. M. Arruando pelo beco: um nome do passado evocado no afeto e no desamor da gente da cidade. Revista de Geografia, PPGEO, vol. 2, n ${ }^{\circ}$, 2012 .

MACIEL, C. A. A. Metonímias Geográficas Imaginação e retórica da paisagem no semiárido pernambucano. Programa de Pós-Graduação em Geografia, Universidade Federal do Rio de Janeiro (Tese de doutorado). UFRJ, 2004.

A retórica da paisagem: um instrumento de interpretação geográfica. Espaço e Cultura, UERJ, RJ, nº. 26, p. 32-48, jul./dez. de 2009

MACIEL, C. A. A.; VASCONCELOS, P. B. Fotografia de paisagem: uma retórica contundente acerca da natureza. In: JACINTO, R. (Org.). Transversalidades 2016 - Fotografia sem fronteiras. $1^{\mathrm{a}}$ ed. Guarda (Portugal): Centro de Estudos Ibéricos, 2016, vol. 1, p. 50-54.

MELlo, J. A. G. Tempo dos Flamengos: Influência da Ocupação Holandesa na Vida e na Cultura do Norte do Brasil. $4^{\mathrm{a}}$ ed. Rio de Janeiro: Topbooks Editora, 2001.

MENEZES, J. L. M. A ocupação do Recife numa perspectiva histórica. Série Histórica do Nordeste Recife vol. $1 \mathrm{n}^{\circ} 14$, p.147-162, 1993. Disponível em:

http://www.revista.ufpe.br/revistaclio/index.php /revista/article/viewFile/827/675

Acesso em: 31 de maio de 2017.

O universo encantado de Cláudio Dubeux. In: CÂMARA, B. A. D; SOUZA, G. F. C. S. et al. O fotógrafo Cláudio Dubeux. Recife: Cepe, 2011 , p.187-221.

Ruas sobre as águas. As pontes do Recife. Recife: Cepe, 2015.
MENEZES, L. R. de. Habitar no centro histórico: a habitação de interesse social como instrumento de reabilitação do Centro Histórico do Recife. Recife: Dissertação (Mestrado em Desenvolvimento Urbano) - Centro de Artes e Comunicação, Universidade Federal de Pernambuco, 2015.

MENESES, U. T. B. Fontes visuais, cultura visual, História visual. Balanço provisório, propostas cautelares. Revista Brasileira de História, vol.23, $\mathrm{n}^{\circ} 45$, São Paulo: USP, julho de 2003. Disponível em:

http://www.scielo.br/scielo.php?script=sci_arttex t\&pid=S0102-01882003000100002\#top78\%20. Acesso em: 31 de maio de 2017.

OUEllet, P. Poétique du regard, SilleryLimoges, Septentrion-Pulim, 2000.

PESAVENTO, S. J. "Era uma vez o beco: origens de um mau lugar". In: Palavras da Cidade. Rio Grande do Sul: Editora da Universidade, 2001. p. 97-120.

PONTUAL, V. Tempos do Recife: representações culturais e configurações urbanasRevista Brasileira de História. São Paulo, v. 21, n 42, p. 417-434. 2001.

REZENDE, A. P. O Recife: histórias de uma cidade. Recife: Fundação de Cultura da Cidade do Recife, 2002.

REYNALDO, A. As catedrais continuam brancas: planos e projetos do século XX para o centro do Recife. Recife: Cepe, 2017.

SETTE, M. Arruar, história pitoresca do Recife Antigo. $2^{\text {a }}$ ed. Rio de Janeiro: Casa do Estudante do Brasil, 1948.

SILVA, J. B. Nas trilhas da cidade. Fortaleza: Museu do Ceará, 2001.

WYLIE, J. Landscape. London: Routledge, 2007. 


\section{IN THE DEEPEST BOWELS OF THE CITY: IMAGES AND SPATIALITIES OF THE LANES IN THE HISTORIC CENTER OF RECIFE}

ABSTRACT: THE LANES OF tHE HISTORIC CENTER OF RECIFE ARE A SOCIO-SPATIAL HERITAGE OF LUSO-BRAZLLIAN URBANISM

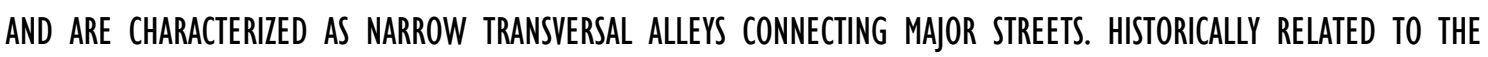
SOCIABILITY OF THE POOREST, THEY SUFFERED, THEREFORE, A PROCESS OF CONCEALMENT IN THE REPRESENTATIVE ICONOGRAPHY OF THE CITY, ALTHOUGH BEING SPACES OF INTENSE SERVICES AND COMMERCIAL FLOW. AS PLACES IMBRICATED IN THE URBAN FABRIC, THEY SEEM UNATtRACTIVE TO THE CONTEMPLATIVE GAZE, OR UNWORTHY OF RECORDING IN ENGRAVINGS AND PHOTOGRAPHS. THUS, thE RESEARCH StaRTS FrOM tHE OBSERVATION OF thE EMPIRICAL PROBLEM OF THE INVISIBILITY OF THESE ALLEYS IN THE HISTORIC HERITAGE BLOCKS OF SÃO JOSÉ AND SANTO ANTÔNIO, IN ORDER TO REFLECT ON THEIR SPATIALITY. IT IS BASED ON THE CONCEPTUAL KEY OF tHE NON - PANORAMIC LANDSCAPE, IN AN INVESTIGATIVE APPROACH CENTERED ON THE PRODUCTION OF ORIGINAL PHOTOGRAPHS AS A CONCRETE DEVICE tHAT LEADS TO DISCOVERIES ABOUT THE RELATION BETWEEN PERCEIVING AND PRODUCING IMAGES OF THE WORLD.

KEYWORDS: ALLEYS, PHOTOGRAPHY, NON-PANORAMIC LANDSCAPE, HISTORICAL CENTER, RECIFE.

\section{EN LAS ENTRANAS MÁS PROFUNDAS DE LA CIUDAD: IMÁGENES Y ESPACIALIDAD DE LAS CALLEJAS EN LO CENTRO HISTÓRICO DE RECIFE}

RESUMEN: LOS CALLEJONES DEL CENTRO HISTÓRICO DE RECIFE SON UNA HERENCIA SOCIO-ESPACIAL DEL URBANISMO LUSOBRASILEÑO, CARACTERIZÁNDOSE COMO ESTREChAS VÍAS tranSVERSALES DE CONEXIÓN ENTRE CALLES PRINCIPALES. HISTÓRICAMENTE RELACIONADOS A LA SOCIABILIDAD DE LOS MÁS POBRES, SUFRIERON, POR CONSIGUIENTE, UN PROCESO DE OCULTACIÓN EN LA ICONOGRAFía REPRESENTATIVA DE LA CIUDAD, AUNQUE SEAN ESPACIOS DE INTENSO FLUJO COMERCIAL Y DE SERVICIOS. COMO LUGARES RECÓNDITOS EN EL tejIDO URBANO, PARECEN POCO ATRACTIVOS A LA MIRADA CONTEMPLATIVA, $O$ INDIGNOS DE REGISTRO EN GRABADOS Y FOTOGRAFÍAS. LA INVESTIGACIÓN CONSIDERA LA CONSTATACIÓN emPírica de la INVISIBILIZACIÓN DE ESAS CALLEJUELAS EN EL CONJUNTO DEL PERÍMETRO PATRIMONIALIZAdO DE LOS baRRIOS DE SAN JOSÉ Y SANTO ANTÔNIO PARA REALIZAR UNA REFLEXIÓN SOBRE SU ESPACIALIDAD. SE PARTE DE LA CLAVE CONCEPTUAL del PaISAJE NO PANORÁmiCO EN UN RECORRIDO INVESTIGATIVO BASADO EN LA PRODUCCIÓN DE FOTOGRAFías PROPIAS, COMO UN DISPOSITIVO CONCRETO QUE CONDUCE A DESCUBRIMIENTOS SOBRE LA RELACIÓN ENTRE PERCIBIR Y PRODUCIR IMÁGENES DEL MUNDO.

palabras ClaVE: CallejONES, FOTOGRAFía, PaISAJE NO PANORÁMICA, CENTRO HISTÓRICO, RECIFE. 